\title{
Pesticide Contamination in Groundwater and Streams Draining Vegetable Plantations in the Ofinso District, Ghana
}

\author{
Benjamin O. Botwe ${ }^{1}$, William J. Ntow ${ }^{2}$ and Elvis Nyarko ${ }^{1}$ \\ 1 University of Ghana, Department of Oceanography $\mathcal{E}$ Fisheries \\ ¿University of California, Department of Plant Sciences \\ ${ }^{1}$ Ghana \\ 2USA
}

\section{Introduction}

\subsection{Ghana's geographical location and climate}

Ghana, officially the Republic of Ghana and formerly the Gold Coast, is a West African country with a geographical location of $5^{\circ} 36^{\prime} \mathrm{N}, 0^{\circ} 10^{\prime} \mathrm{E}$. It shares borders with Cote d'Ivoire to the west, Burkina Faso to the north and Togo to the east. To the south of the country is the Gulf of Guinea of the Atlantic Ocean. The climate is tropical equatorial ranging from the bimodal rainfall equatorial type in the south to the tropical unimodal monsoon type in the north. It is influenced by the hot, dry and dusty-laden air mass that moves from the northeast across the Sahara and by the tropical maritime air mass that moves from the south-west across the southern Atlantic ocean. The annual rainfall ranges from 1015 to $2300 \mathrm{~mm}$ with annual mean temperature and relative humidity of $30^{\circ} \mathrm{C}$ and $80 \%$ respectively (Ntow \& Botwe, 2011). Ghana has a total land area of about 23,853, 900 ha and a population of about 24.2 million. The arable land covers an area of about 13,628,179 ha (approx. 57\% of total land area) of which approximately $44 \%$ is under cultivation.

\subsection{Economic importance of agriculture in Ghana}

Agriculture is Ghana's most important economic sector, employing more than $60 \%$ of the labour force. Currently, agriculture contributes about 33\% of Ghana's gross domestic product (GDP) and accounts for over $40 \%$ of export earnings. Ghana's agriculture is predominantly smallholder, traditional and rain-fed. The major agro-ecological zones in Ghana are Rain Forest, Deciduous Forest, Forest-Savannah Transition, Coastal Savannah and Northern (Interior) Savannah which comprises Guinea and Sudan Savannahs. The type of agricultural activity carried out in each zone is determined largely by rainfall. In the south, there is a major and a minor growing season due to the bimodal rainfall pattern in the Forest, Deciduous Forest, Transitional and Coastal Savannah zones whereas in the Northern Savannah, the unimodal rainfall pattern results in a single growing season. Within the agricultural sector, vegetable production plays an important socio-economic role, having developed from a mainly subsistence activity to a commercial activity. Vegetable production in Ghana typically occurs in intensely managed vegetable plantations characterized by an 
extensive network of drainage systems through which surplus water may flow out (Ntow et al., 2008). Vegetables cultivated in Ghana include tomato (Lycopersicon esculentum), eggplant (Solanum melongena), pepper (Capsicum annum) and onion (Allium cepa), although some regions are more efficient and specialised in the production of only one or two vegetable crops (Ntow, 2001).

\subsection{Pesticide use in vegetable cultivation in Ghana}

Vegetables generally attract a wide range of pests and diseases, and require intensive pest management (Dinham, 2003), which includes all aspects of the safe, efficient and economic use and handling of pesticides. In Ghana, pest and disease control practices in vegetable production involve the use of chemical pesticides. A total of 43 pesticides, comprising insecticides, fungicides and herbicides, have been found in use in vegetable farming in Ghana. Among these pesticides, the herbicides class of pesticides is the most used $(44 \%)$, followed by insecticides (33\%) and then fungicides (23\%) (Ntow et al., 2006). Although it is recognized that better management of pesticides results in high crop productivity while greatly reducing adverse environmental impacts, most of the local farmers lack adequate training in the proper application of pesticides. Pest and disease control therefore involves relatively high inputs of highly toxic chemical pesticides which are most of the time misapplied (Ntow et al., 2006). The average pesticide application rate is estimated to be 0.08 litres active ingredient (a.i.) per hectare (Ntow et al., 2008). Misapplication and intensive use of pesticides in vegetable cultivation can result in pesticide contamination of the environment.

\subsection{Impacts of pesticide use in vegetable agro-ecosystems}

Water pollution by pesticides has long been recognized as a major environmental impact associated with agriculture due to the potential adverse effects on aquatic life and on humans if contamination extends to drinking waters (Skinner et al., 1997). Most vegetable farms in Ghana are sited a few meters from streams for easier access to water for irrigation purposes. The close proximity of streams to vegetable farms is of particular concern as there is high potential for pesticides to move offsite into surrounding streams via run-off through the extensive system of drainage canals that characterize these farms. Persistent pesticides, particularly the organochlorine group of pesticides, can be transferred to aquatic organisms at all trophic levels within the food chain due to their bioconcentration and bioaccumulation potential. Many organochlorine pesticides are known to mimic hormones and disrupt reproductive cycles of humans and wildlife (Colborn and Smolen, 1996) and therefore they can be detrimental to a wide variety of aquatic wildlife populations (Robinson, 1991). Even non-persistent pesticides, such as the pyrethroids, carbamates and organophosphate group of pesticides, can be highly toxic to aquatic life (Castillo et al., 2006). Pesticides can also enter groundwater via seepage or soil percolation. Pesticides contamination of streams and groundwater also presents health threat to the rural communities as they depend on streams and groundwater for drinking and other domestic purposes.

Concerns over the adverse ecological and human health impacts of pesticides have led to the institution of very strict programs to control and monitor pesticide contamination in water sources in developed countries such as the United States and members states of the European Community (García de Llasera and Bernal-González, 2001). These programs have, however, not been implemented in most developing countries such as Ghana. Few studies 
conducted in Ghana have focused on the organochlorine pesticides (Osafo \& Frimpong, 1998; Ntow, 2001, 2005). However, pesticides from the organophosphate group, which are now commonly used in Ghana following the ban on persistent organochlorine pesticides, have not been determined in water quality studies. In this chapter, pesticide contamination in groundwater and streams draining vegetable plantations in the Ofinso District of Ghana are assessed and the ecotoxicological significance of the pesticides contamination evaluated.

\subsection{Study area}

The present study was conducted in the Ofinso District of the Ashanti Region of Ghana (Fig. 1). The Ofinso District is located in the extreme North-Western part of the Ashanti Region, with about half of its boundaries bordered by Brong Ahafo Region (in the north and west).

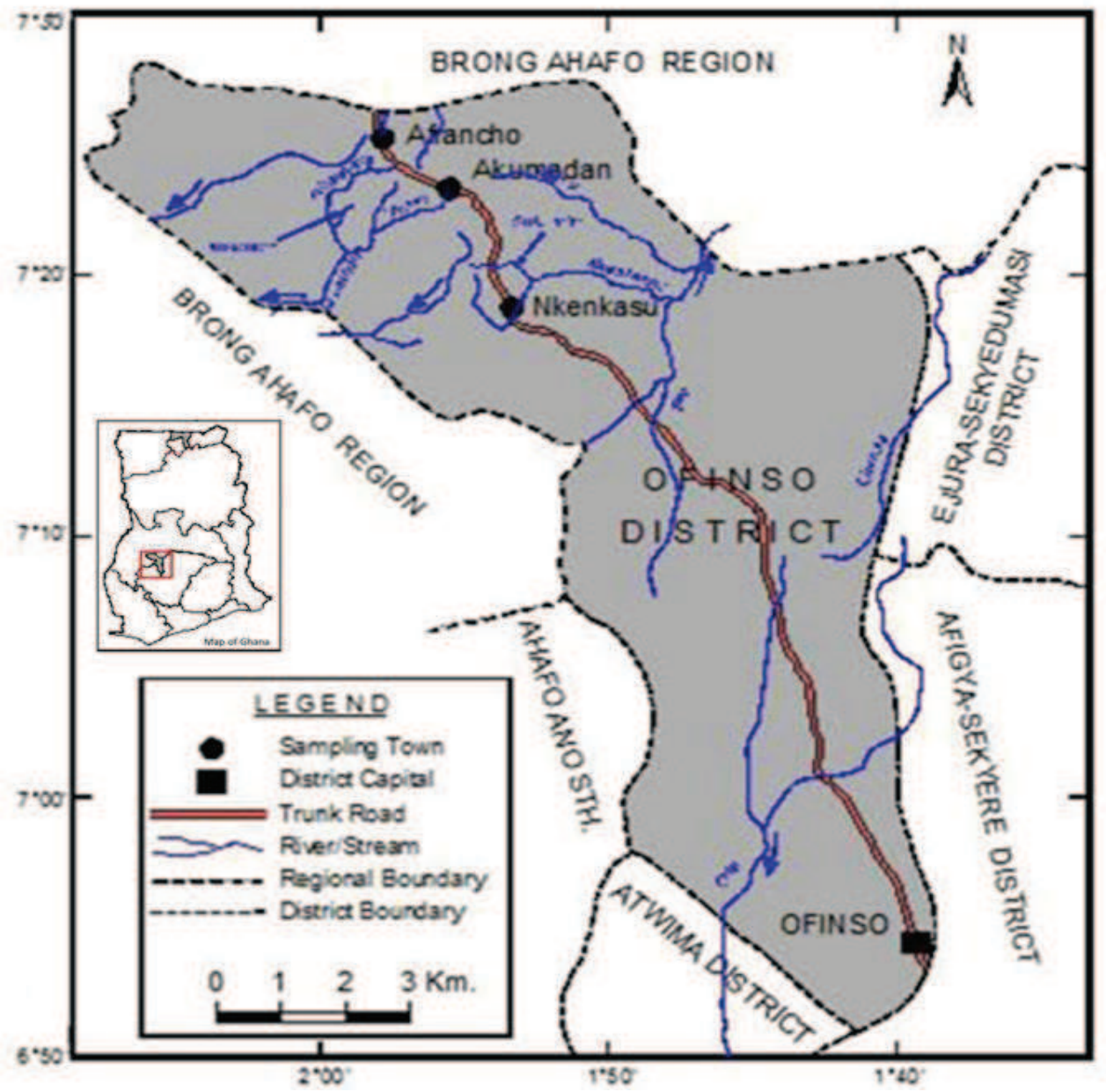

Fig. 1. Map showing the study area 
It is bordered to the east by Ejura-Sekyedumasi District, to the south by Afigya Sekyere, Ahafo Ano South and Atwima Districts. The district has 126 settlements and a population of about 35,190 with New Ofinso as its capital. The district has five towns namely Abofour, Nkenkasu, Afrancho, Akumadan and New Ofinso. The study area is within the Ofin, Pru and Afram river basins. In the present study, vegetable plantations were selected from Akumadan, Nkenkasu, and Afrancho. Agriculture is the main economic activity in these areas with over $70 \%$ of the active population being farmers. The district is well known for the cultivation of vegetable crops. Other major crops cultivated include cassava, maize, plantain and cocoa. More than 23 different active ingredients formulated as insecticides, herbicides and fungicides have been used in the cultivation of vegetables in the district.

The five most frequently used insecticides include two organophosphates (chlorpyrifos and dimethoate), two pyrethroids (lambda-cyhalothrin and cypermethrin), and one organochlorine (endosulfan). Farmers use these highly toxic pesticides under primitive field conditions with insufficient protective equipment and training. Pesticide applications occur frequently, all year round, and are relatively intensive (500-1000 ml/ha). Pesticides are also sprayed in combinations, with many farmers $(60 \%)$ spraying their crops on calendar basis, at 7-day intervals (Ntow et al. 2006). Streams within the catchments of vegetable farmlands are vulnerable to pesticide contamination as a result of spray drift and surface runoff (Maule et al., 2007). The quality of these water resources is of critical interest as they serve as aquatic habitats and drinking water sources.

\section{Methods}

\subsection{Sampling of stream water, sediment and groundwater}

Twenty-one streams flowing in and/or around vegetable plantations, stream-bed sediments and 9 drinking water wells in the Ofinso District of the Ashanti Region of Ghana were sampled between February 2008 and January 2009 as part of a pesticide monitoring programme in vegetable agro-ecosystems in Ghana. Streams sampled included Akumadan, Nkenkasu and Afrancho (Fig. 1) which flow in and around vegetable farmlands. The other streams sampled in the district were ephemeral and these included Srani, Bosompong, Sukubrim, Siasu, Ankonom, and Naasu (not shown). For each stream, $1 \mathrm{~L}$ water samples were collected into 1-L glass amber coloured bottles with Teflon-lined caps from upstream, mid-stream and downstream. During the same period, stream-bed sediment samples of about $200 \mathrm{~g}$ were collected into wide-neck glass jars. Groundwater samples were extracted from drinking water wells located within farming communities at Akumadan, Nkenkasu, and Afrancho into 1-L glass amber coloured bottles with Teflon-lined caps. None of the wells sampled was in a farmed section of the study area. All the wells are shallow wells (< $15 \mathrm{~m}$ ) and represent unconfined aquifers. The wells receive water from the soil and upper porous rock zones that characterise the Ofinso District. Prior to sampling, pumps were run for about $5 \mathrm{~min}$ to clear the casing of standing water and to bring in fresh water from the aquifer. During this period, field measurement parameters (e.g. temperature) were stabilised. The sampling bottles were rinsed with well water before taking the water samples. Three replicates were collected from each well. The samples were transported to the laboratory within 24 to $48 \mathrm{~h}$ on ice in clean ice chests and stored in the laboratory refrigerator at $4{ }^{\circ} \mathrm{C}$ until analysed. The samples were extracted within $24 \mathrm{~h}$ of arrival at the laboratory. Field blanks were prepared with distilled water and were analysed only when 
pesticide residues were detected in primary samples. Sampling was conducted throughout rainy and dry seasons and was not timed to applications of different pesticides or to rain events.

\subsection{Chemical analysis}

\subsubsection{Sample extraction}

The extraction and analyses of water samples were performed following the Association of Official Analytical Chemists 990.06 and 970.52 methods as described by Ntow et al. (2008). Briefly, water samples were extracted sequentially three times with $25 \mathrm{~mL} n$-hexane each time. The extract was dried with anhydrous sodium sulphate and concentrated down to 10 $\mathrm{mL}$ by means of ultrasonic bath type concentrators (Turbo Vap II). Extract clean up was done, using a chromatographic column, packed with florisil, previously activated for $3 \mathrm{~h}$ in an oven at $130^{\circ} \mathrm{C}$, and anhydrous sulphate (all rinsed with petroleum ether). The extract was transferred to the column. Three fractions were obtained after elution with $6,15,50 \%$ ethyl ether in petroleum ether. Maximal flux rate of elution was $5 \mathrm{~mL} / \mathrm{min}$. Each eluate was evaporated and the extracts (re-dissolved in $1.5 \mathrm{ml} n$-hexane and made up to $2 \mathrm{ml}$ with more $n$-hexane) were injected into a gas chromatographic system for identification and quantification of the pesticides.

Extraction and analysis of sediment samples followed the method described by Ntow et al. (2008). Briefly sediment samples were well mixed to obtain a homogeneous sample and then transferred into a pan to air-dry at ambient temperature until a constant weight was obtained. The samples were later ground in a mortar into fine powder such that they could pass through $2 \mathrm{~mm}$ sieve. Five grams (dry weight) of the sediment samples were soxhlet extracted in methanol, and cleaned up in florisil in the same way as described above for water. Sampling protocol and analytical procedures were subjected to quality control through field and laboratory blanks and spiking of samples with pesticide standards.

Laboratory glassware used in the sampling and analyses were cleaned as described by Ntow (2001). Pesticide grade solvents used for the analyses were $n$-hexane $(>99 \%)$ and acetone (>99.9\%) (Sigma, Munich, Germany); methanol (99.8\%) and petroleum ether (BDH; VWR International, UK); dichloromethane and ethyl ether (Fluka; Munich, Germany). Deionised water was used from a Milli-Q water purification system (Millipore, Bedford, MA, USA) for blanks, sediment extraction, and spiked samples. Pesticide standards (> 98\% purity) were obtained from Dr. Ehrenstorfer (Augsburg, Germany). Standard mixtures were prepared from individual pesticide stock solutions (50-100 $\mathrm{mg}$ in $100 \mathrm{ml}$ acetone) and then diluted to working calibration standards at three concentration levels with acetone/cyclohexane (pesticide grade) mixture (1:9).

\subsubsection{Pesticide residue analysis}

Measurement of pesticide compounds in water and sediment samples was performed on a GC-MS (Agilent 6890 Series GC System) coupled with an Agilent 5973N mass selective detector-electron impact ionization; and fused capillary column (HP-5MS) packed with 5\% Phenyl Methyl Siloxane ( $30 \mathrm{~m} * 0.25 \mathrm{~mm}$ I.D and film thickness $0.25 \mu \mathrm{m}$ ), which was operated in the selected ion-monitoring mode at the following conditions: injection port $250^{\circ} \mathrm{C}$ (splitless, pressure $22.62 \mathrm{psi}$; purge flow $50 \mathrm{~mL} / \mathrm{min}$; purge time $2.0 \mathrm{~min}$; total flow $55.4 \mathrm{~mL} / \mathrm{min})$. Column oven: initial $70^{\circ} \mathrm{C}$, held $2 \mathrm{~min}$, programming rate $25^{\circ} \mathrm{C} / \mathrm{min}$ (70 to $\left.150^{\circ} \mathrm{C}\right) ; 10^{\circ} \mathrm{C} / \mathrm{min}\left(150\right.$ to $\left.200^{\circ} \mathrm{C}\right) ; 8^{\circ} \mathrm{C} / \mathrm{min}\left(200\right.$ to $\left.280^{\circ} \mathrm{C}\right)$ and held $10 \mathrm{~min}$ at $280^{\circ} \mathrm{C}$. The 
carrier gas was nitrogen at $15 \mathrm{psi}$; detector make-up, $30 \mathrm{~mL} / \mathrm{min}$. The injection volume was $1 \mu \mathrm{L}$ (Agilent 7683 Series injector). Selection of analysed pesticides was done on the basis of pesticide use information provided by Ntow et al. (2006). The pesticides analysed included a- and $\beta$-endosulfan, endosulfan sulphate, dieldrin, dichlorodiphenyltrichloroethane $\left(\mathrm{p}, \mathrm{p}^{\prime}\right.$ DDT), dichlorodiphenyldichloroethylene ( $\mathrm{p}, \mathrm{p}^{\prime}$-DDE) and chlorpyrifos. For quality control of gas chromatographic conditions, a checkout procedure was performed before sample analysis in which a standard mixture with a-endosulfan content of $400 \mathrm{ng} / \mathrm{L}$ was used. Calibration was carried out when the concentration of $\alpha$-endosulfan in standard mixture deviated significantly from $400 \mathrm{ng} / \mathrm{L}$. Also the linearity of detector response was checked with five standard solutions of concentration 200 - $1000 \mathrm{ng} / \mathrm{L}$. The correlation coefficient, $\mathrm{r}$, obtained was $\geq 0.94$. Recovery of the different pesticides ranged between $79 \%$ and $104 \%$ and their detection limits varied between 0.001 and $0.01 \mu \mathrm{g} / \mathrm{L}$. The residues are expressed as $\mu \mathrm{g} / \mathrm{L}(\mathrm{ppb}$ ) for surface water and $\mu \mathrm{g} / \mathrm{kg}$ dry weight (ppb) for sediment. Because most of the pesticides analysed by GC/MS had a method detection limit at or below $0.01 \mu \mathrm{g} / \mathrm{L}$, the reporting limit was chosen as $0.01 \mu \mathrm{g} / \mathrm{L}$ for these compounds. This reporting limit was used in calculating incidences of occurrence. A pesticide that has been identified but not quantified is indicated as below the detection limit.

\subsubsection{Physicochemical analysis}

The $\mathrm{pH}$ and temperature of samples were determined in situ using a $\mathrm{pH}$ meter. The $\mathrm{pH}$ meter was first calibrated with standard $\mathrm{pH}$ buffers before immersing the probe into the water or sediment. Temperature was measured concurrently. Total suspended solids and turbidity in water were measured using a turbidity meter (2100P Turbidimeter, Hach Company, Loveland, CO, USA). Calibration of the turbidity meter was done by filtering some water samples through pre-weighed Whatman GF/F ( $0.45 \mu \mathrm{m}$ pore-size) glass microfiber filters which were then dried at $60^{\circ} \mathrm{C}$ for $48 \mathrm{~h}$ and re-weighed to determine TSS. Water content (expressed as weight fraction of water) was determined by first weighing wet sediment samples, then ovendrying the sediment samples at $105^{\circ} \mathrm{C}$ until constant weight, and obtaining the weight difference. Total suspended solids and turbidity were measured concurrently (Ntow et al., 2008). Total organic carbon was obtained from the percentage organic matter in the sediments as percentage loss-on-ignition after drying $1.0 \mathrm{~g}$ of the sediment samples (previously acidified for the removal of carbonates) at $550^{\circ} \mathrm{C}$ in a furnace (Mwamburi, 2003).

\subsection{Statistical analysis}

A paired Student's $t$ test was performed to analyze significant differences between pesticide residue levels in stream water and stream-bed sediment. One-way analysis of variance (ANOVA) was performed to analyze significant differences in pesticide residue levels in water and sediment from different sites. Pearson correlation analysis was performed to determine the relationship between the levels of pesticide residues and sediment characteristics (total suspended solids and total organic carbon) at the $95 \%$ confidence level $(p<0.05)$

\subsection{Ecotoxicological significance of measured pesticides in stream water}

The effects of pesticides on water quality are commonly assessed by comparing the observed concentrations of individual pesticide compounds in the aquatic system with criteria that have been established to protect the health of aquatic organisms (Castillo et al. 2000; Hoffman et al. 2000). By comparing the pesticide concentrations in this study with the 
toxicity values listed in Table 1, the acute and chronic risk ratios were calculated for the water samples. A ratio of 1 means the individual pesticide has reached its criteria concentration in the streams. Risk for acute toxicity is based on the highest pesticide concentration found compared to the $\mathrm{LC}_{50}$ (Table 1). Risk for chronic toxicity is calculated based on the average concentration of all positive observations and the water quality criteria (Table 1).

\begin{tabular}{|c|c|c|c|}
\hline Pesticides & Main use & $\begin{array}{l}\text { Lowest } \mathrm{LC}_{50} \text { for } \\
\text { crustaceans or fish }\left(\mu \mathrm{gL} \mathrm{L}^{-1}\right) \\
(\text { EXTOXNET 1996) }\end{array}$ & $\begin{array}{l}\text { Water-quality } \\
\text { criterion }\left(\mu \mathrm{gL}^{-1}\right) \\
\text { (USEPA 1999) }\end{array}$ \\
\hline a-Endosulfan & Insecticide & 1.20 & 0.056 \\
\hline$\beta$-endosulfan & Insecticide & 1.20 & 0.056 \\
\hline Endosulfan sulphate & Insecticide & 1.20 & 0.056 \\
\hline Dieldrin & Insecticide & - & 0.056 \\
\hline Chlorpyrifos & Insecticide & 0.01 & 0.041 \\
\hline $\mathrm{p}, \mathrm{p}^{\prime}-\mathrm{DDE}$ & Insecticide & 0.18 & 0.001 \\
\hline $\mathrm{p}, \mathrm{p}^{\prime}-\mathrm{DDT}$ & Insecticide & 0.18 & 0.001 \\
\hline
\end{tabular}

Table 1. Reference toxicity values for pesticides analyzed

\section{Results and discussion}

\subsection{Physicochemical characteristics of water and sediment samples analyzed}

The physicohemical characteristics of groundwater, stream water and sediment samples analyzed are presented in Table 2 .

\begin{tabular}{|l|c|c|c|}
\hline \multicolumn{1}{|c|}{ Physicochemical parameter } & Groundwater & Stream water & Sediment \\
\hline $\mathrm{pH}$ & $5.8-6.4$ & $6.6-8.3$ & $5.6-6.8$ \\
Temperature $\left({ }^{\circ} \mathrm{C}\right)$ & $21.4-22.7$ & $23.2-27.4$ & - \\
Total suspended solids (mg/l) & 0 & $5.8-20.6$ & - \\
Turbidity (NTU) & $0.74-2.93$ & $2.2-32.5$ & - \\
Moisture content $(\%)$ & - & - & $18.0-26.3$ \\
Total organic carbon $(\%)$ & - & - & $2.1-13.6$ \\
\hline
\end{tabular}

Table 2. Physicohemical characteristics of groundwater, stream water and sediment samples analyzed

The $\mathrm{pH}$ and turbidity of groundwater were within acceptable levels for human consumption. The $\mathrm{pH}$, temperatures, levels of total suspended solids and turbidity of stream water were also suitable for aquatic life.

\subsection{Pesticide residue levels in groundwater}

Pesticide residues were not detected in all the groundwater samples analyzed (Table 3). The non-detection of pesticide residues in groundwater could be due to their high adsorption to soil particles which does not facilitate their infiltration into groundwater. This is an indication that groundwater consumption may not contribute to community exposure to these pesticides. 


\begin{tabular}{|c|c|c|c|c|c|c|}
\hline \multirow{2}{*}{$\begin{array}{c}\text { Pesticide } \\
\text { components }\end{array}$} & \multicolumn{2}{|c|}{ Groundwater $(\mathrm{n}=81)$} & \multicolumn{2}{|c|}{ Stream water $(n=192)$} & \multicolumn{2}{|c|}{ Sediment $(n=180)$} \\
\hline & $\begin{array}{c}\text { Mean } \pm \text { SD } \\
\left(\mu \mathrm{gL}^{-1}\right)\end{array}$ & $\begin{array}{l}\text { I.R } \\
(\%)\end{array}$ & $\begin{array}{c}\text { Mean } \pm \text { SD } \\
\quad\left(\mu \mathrm{gL}^{-1}\right)\end{array}$ & $\begin{array}{l}\text { I.R } \\
(\%)\end{array}$ & $\begin{array}{l}\text { Mean } \pm \text { SD } \\
\left(\mu \mathrm{gKg}^{-1} \mathrm{dw}\right)\end{array}$ & $\begin{array}{l}\text { I.R } \\
(\%)\end{array}$ \\
\hline a- Endosulfan & ND & - & $0.027 \pm 0.015$ & 27.8 & $0.38 \pm 0.24$ & 90.0 \\
\hline$\beta$-Endosulfan & ND & - & $0.021 \pm 0.010$ & 13.9 & $0.18 \pm 0.09$ & 97.5 \\
\hline $\begin{array}{l}\text { Endosulfan- } \\
\text { sulphate }\end{array}$ & ND & - & $0.022 \pm 0.010$ & 21.5 & $0.53 \pm 0.24$ & 98.3 \\
\hline Dieldrin & ND & - & ND & - & $0.16 \pm 0.04$ & 35.0 \\
\hline $\mathrm{p}, \mathrm{p}^{\prime}-\mathrm{DDE}$ & ND & - & ND & - & $3.77 \pm 1.90$ & 25.0 \\
\hline $\mathrm{p}, \mathrm{p}^{\prime}-\mathrm{DDT}$ & ND & - & ND & - & ND & - \\
\hline Chlorpyrifos & ND & - & ND & - & $1.23 \pm 0.40$ & 68.3 \\
\hline
\end{tabular}

Table 3. Concentrations (Mean \pm SD) and incidence ratios of pesticide residues in groundwater, stream water and stream-bed sediment samples analyzed. $[\mathrm{n}=$ number of samples analyzed; $\mathrm{SD}=$ standard deviation; $\mathrm{ND}=$ below detection limit $\left(0.01 \mu \mathrm{gL}^{-1} \mathrm{or}\right.$ $\left.\mu \mathrm{gKg}^{-1}\right) ; \mathrm{I} . \mathrm{R} .=$ incidence ratio; $\mathrm{dw}=$ dry weight]

\subsection{Pesticide residue levels in stream water}

The mean concentrations and incidence of occurrence of pesticides detected in stream water are summarized in Table 3. Only 67 (35\%) of the 192 stream water samples analyzed had pesticide residue detections. $\alpha$-endosulfan, $\beta$-endosulfan and endosulfan sulphate were the only pesticide residues detected with mean concentrations of $0.027 \pm 0.015,0.021 \pm 0.010$, and $0.022 \pm 0.010 \mu \mathrm{gL}^{-1}$ (or ppb), respectively. The incidence of occurrence of these organochlorine pesticide residues were a-endosulfan $(27.8 \%), \beta$-endosulfan $(13.9 \%)$ and endosulfan $(21.5 \%)$. Technical endosulfan is a mixture of $\alpha$ - and $\beta$-endosulfan in a ratio of 7:3. Endosulfan sulfate is the principal metabolite of endosulfan and it is highly toxic. Endosulfan sulfate levels in stream water samples were nearly equal to those of the parent compounds ( $\alpha$ - and $\beta$-endosulfan), suggesting current use of the pesticide. The occurrence of endosulfan residues in streams may be the result of direct overspray, spray drift, atmospheric transport of volatilized pesticides, agricultural runoff, pesticide misuse, and improper disposal of pesticide containers (Maule et al., 2007; Wan et al., 2005; Ntow et al., 2008). Inflows from shallow groundwater originating in the agricultural areas are however unlikely sources of pesticide contamination in the streams studied since pesticide residues were not detected in groundwater samples analyzed in the present study.

Pearson correlation analysis revealed an association $\left(r^{2}>0.6\right)$ between endosulfan residue concentration and total suspended solids in stream water for most sites. Thus, increase in the level of suspended solids (sediment) resulted in a corresponding increase in concentration of endosulfan. This partitioning behavior of endosulfan in the streams studied may be influenced by physicochemical properties. Endosulfan has low water solubility $(0.32$ $\mathrm{mgL}$ at $22^{\circ} \mathrm{C}$ ) and high affinity for sediment as indicated by the high soil adsorption coefficient of 2,400 $\mathrm{mLg}^{-1}$ which can be attributed to its high octanol-water partitioning coefficient $(\log K o w=3.6)$ (see Table 4$)$. Therefore, with these properties, there is a high tendency for endosulfan to adsorb onto suspended sediments in the water column than to remain in solution as the study has shown. 


\begin{tabular}{|l|c|c|c|c|}
\hline \multicolumn{1}{|c|}{ Pesticide name } & $\begin{array}{c}\text { Water solubility at } \\
\text { given temperature } \\
\left(\mathrm{mgL}^{-1}\right)\end{array}$ & LogKow & $\begin{array}{c}\text { Soil adsorption } \\
\text { coefficient, } K_{\mathrm{oc}} \\
\left(\mathrm{mLg}^{-1}\right)\end{array}$ & $\begin{array}{c}\text { Soil half- } \\
\text { life }\end{array}$ \\
\hline $\begin{array}{l}\text { Endosulfan }(\mathrm{\alpha}, \beta \\
\text { and sulfate })\end{array}$ & $0.32\left(22^{\circ} \mathrm{C}\right)$ & 3.6 & 2,400 & $50 \mathrm{~d}$ \\
Dieldrin & - & 5.5 & - & - \\
DDE & $<1\left(20^{\circ} \mathrm{C}\right)$ & 5.8 & 100,000 & $2-15$ years \\
Chlorpyrifos & $2\left(25^{\circ} \mathrm{C}\right)$ & 4.7 & 6,070 & $35-78 \mathrm{~d}$ \\
\hline
\end{tabular}

Table 4. Properties of pesticides detected in streams. Source: EXTOXNET (1996)

Endosulfan is banned or restricted in many countries because of its human health and environmental impacts. In the United States, for example, endosulfan is applied to grains, tea, fruits, vegetables, tobacco, and cotton (DeLorenzo et al. 2001). In Ghana, endosulfan has a restricted use that does not include vegetables (it has only been registered for use on cotton), yet it is used on vegetables. According to Ntow et al. (2006), endosulfan is one of the most commonly used pesticides in the study area. Different formulations of the active ingredient are sold in the study area under different trade names such as Thionex 35 EC/ULV, Thiodan 50 EC, Endosulfan, Endocoton, Caiman 350 EC, Phaser and Novasulfan 35 EC. Vegetable farmers in Ghana spray endosulfan on tomato, pepper, okra, egg-plant (garden eggs), cabbage and lettuce. Although there are numerous pests and diseases prominent on vegetables (for instance, there are 13 fungal pathogens on tomato alone), the use of endosulfan was not necessarily to control diseases. Application of endosulfan to control diseases was done on a trial-and-error basis because the local farmers were not able to identify the pests causing damage (Ntow et al., 2006). The use of endosulfan on vegetables by Ghanaian farmers is of great concern due to the persistence and extreme toxicity of endosulfan to fish and aquatic invertebrates (Pérez-Ruzafa et al., 2000). The presence of endosulfan in stream water also has implications for public health as rural communities depend on stream water for drinking. The levels of endosulfan residues obtained in the present study are comparable to those obtained in a previous study by Ntow (2001) (see Table 5).

\begin{tabular}{|l|c|c|c|c|}
\hline \multirow{2}{*}{$\begin{array}{c}\text { Pesticide } \\
\text { components }\end{array}$} & \multicolumn{2}{|c|}{ Stream water $(\mathrm{n}=50)$} & \multicolumn{2}{c|}{ Sediment $(\mathrm{n}=42)$} \\
\cline { 2 - 5 } & $\begin{array}{c}\text { Mean } \pm \text { SD } \\
\left(\mu \mathrm{gL}^{-1}\right)\end{array}$ & $\begin{array}{c}\text { I.R } \\
(\%)\end{array}$ & $\begin{array}{c}\text { Mean } \pm \text { SD } \\
\left(\mu \mathrm{gKg}^{-1} \mathrm{dw}\right)\end{array}$ & $\begin{array}{c}\text { I.R } \\
(\%)\end{array}$ \\
\hline a- Endosulfan & $0.062 \pm 0.007$ & 64 & $0.19 \pm 0.02$ & 90.0 \\
$\beta$-Endosulfan & $0.031 \pm 0.011$ & 60 & $0.13 \pm 0.01$ & 97.5 \\
Endosulfan- & $0.031 \pm 0.012$ & 78 & $0.23 \pm 0.01$ & 98.3 \\
sulphate & - & - & - & 35.0 \\
Dieldrin & $\mathrm{ND}$ & - & $0.46 \pm 0.24$ & 25.0 \\
p,p'-DDE & - & - & - & - \\
p,p'-DDT & - & - & - & 68.3 \\
Chlorpyrifos & & &
\end{tabular}

Table 5. Concentrations (Mean $\pm \mathrm{SD}$ ) and incidence ratios of pesticide residues in stream water and stream-bed sediment. Source: Ntow (2001) 


\subsection{Pesticide residue levels in stream-bed sediment}

The mean concentrations and incidence of occurrence of pesticides detected in stream-bed sediments are summarized in Table 3. Several pesticide residues were detected in the stream-bed sediment samples analyzed compared with stream water samples analyzed. aendosulfan, $\beta$-endosulfan, endosulfan sulfate occurred in at least $90 \%$ of all the sediment samples analyzed while dieldrin, $p, p^{\prime}$-DDE and chlorpyrifos occurred in $25 \%, 35 \%$ and $68 \%$ of all the sediment samples analyzed, respectively. Chlorpyrifos is an organophosphate pesticide while all the other pesticide residues detected belong to the organochlorine group of pesticides.

DDT is well-known to persist in the environment, even in tropical environments (Kidd et al. 2001). Although $p, p^{\prime}$-DDT was not detected in stream water and sediment, its metabolite $p, p^{\prime}$-DDE was detected in sediment at an average concentration of $3.77 \pm 1.90 \mu \mathrm{gKg}^{-1} \mathrm{dry}$ wt. DDE is more persistent in the environment than DDT. Thus, when the use of DDT in a country ceases, its levels are expected to decrease more rapidly while the levels of DDE increases, thereby producing an increasing DDE/DDT ratio. The DDE/DDT ratio is often used as an indicator of recent DDT inputs into the environment; a ratio < 1 indicates recent input (Ballschmiter \& Wittlinger, 1991). The absence of DDT and presence of DDE in sediment could imply the disuse of the parent compound, DDT in Ghana. The relatively high levels of $p, p^{\prime}$-DDE detected in the present study is a justification of the ban of DDT from agricultural use in Ghana. The non-detection of DDT could also confirm the efficacy of the ban on the agricultural use of DDT in Ghana.

Dieldrin and chlorpyrifos were also detected in sediment with mean concentrations of $0.16 \pm$ 0.04 and $1.23 \pm 0.40 \mu \mathrm{gKg}^{-1} \mathrm{dw}$, respectively, although they were not detected in stream water samples. Apart from its usage, dieldrin can occur in the environment as a result of the degradation of a related pesticide, aldrin. Aldrin and dieldrin are persistent in the environment and they have been banned from agricultural use in Ghana (Ntow \& Botwe, 2011). The occurrence of dieldrin in sediment could therefore be due to previous use of dieldrin and/or aldrin. Chlorpyrifos recorded the highest incidence of occurrence $(68 \%)$ in sediment samples. Chlorpyrifos is a broad-spectrum organophosphorus pesticide. Chlorpyrifos, under the trade name Dursban $4 \mathrm{E}$, is a registered insecticide in Ghana for the control of scale borers in cereals, vegetables and ornamentals, and for public health purposes. The occurrence of chlorpyrifos in sediment could be as a result of their current use in vegetable plantations. Residues of chlorpyrifos have also been measured in vegetables from the Ashanti Region (Amoah et al., 2006; Darko \& Akoto, 2008).

Generally, the detected pesticides accumulated in sediment to several times their ambient water concentrations (Fig. 2). Thus, sediment is a better indicator of pesticide pollution than the overlying water. For example, endosulfan (a-endosulfan $+\beta$-endosulfan + endosulfan sulfate) accumulated to over 15 times its ambient water concentration. $p, p^{\prime}$-DDE was also not detected in stream water although it occurred in relatively high concentrations in sediment $\left(3.77 \pm 1.90 \mu \mathrm{gKg}^{-1}\right)$. There was also a significant correlation $\left(r^{2}>0.6\right)$ between levels of pesticide residues and organic carbon content of sediment. This agrees well with the finding that sediment organic matter is the preferential site for the sorption of hydrophobic pollutants (Pignatello, 1998), which includes organochlorine pesticides.

The relatively higher levels of pesticides in sediment than the overlying water can be explained by the fact that pesticides are sequestered by sediments in aquatic systems 
(Reinert et al., 2002), which leads to the accumulation of pesticide residues in sediment over a period of time. The distribution of pesticide residues in water and sediment could be related to their physicochemical properties such as water solubility, soil adsorption coefficient and persistence as shown in Table 4. For example, endosulfan and DDE (organochlorine pesticides) have low water-solubility, high soil adsorption coefficients (Koc) and high persistence in soil, with half-lives between 50 days and 15 years (EXTOXNET, 1996). They are therefore expected to exhibit low degradation in sediment and so were frequently detected in sediments than water. These characteristics imply there could be a direct contribution to the streams from erosion of soil contaminated with these compounds (Munn \& Gruber, 1997). The accumulation of chlorpyrifos in stream-bed sediment is in accordance with its high soil adsorption coefficient, $K_{\mathrm{oc}}$, of $6,070 \mathrm{mLg}^{-1}$ and its half-life of 35 to $78 \mathrm{~d}$ in the water-sediment system.

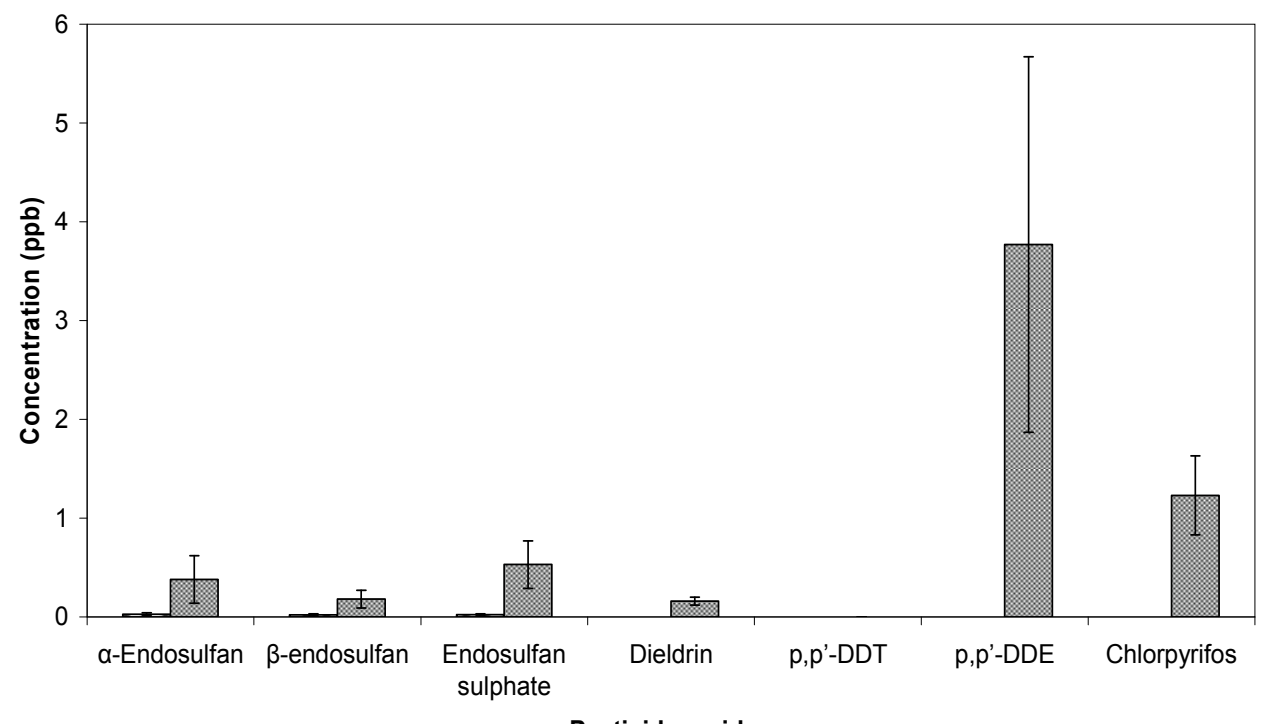

Pesticide residue

DStream water O Sediment

Fig. 2. Pesticide residue concentrations in stream water and underlying sediment

There were also differences in the distribution patterns of endosulfan, dieldrin, DDE and chlorpyrifos in sediment which could be related to the differences in their physicochemical properties. DDE, with the highest $\operatorname{Koc}\left(100,000 \mathrm{mLg}^{-1}\right)$, recorded the highest levels in sediment, followed by chlorpyrifos $\left(K o c=6,070 \mathrm{mLg}^{-1}\right)$ while endosulfan with the lowest Koc $\left(2,400 \mathrm{mLg}^{-1}\right)$ recorded the least concentration. The reverse trend was observed for stream water. The mean level of total endosulfan (a-endosulfan $+\beta$-endosulfan + endosulfan sulfate) in sediment from the present study $\left(1.09 \pm 0.57 \mu \mathrm{gKg}^{-1} \mathrm{dw}\right)$ was not significantly higher $(p>0.05)$ than that obtained from the previous study $(0.54 \pm 0.04 \mu \mathrm{gKg}-1$ 
$\mathrm{dw}$ ) by Ntow (2001). However, the mean sediment DDE level obtained from the present study $\left(3.77 \pm 1.90 \mu \mathrm{gKg}^{-1} \mathrm{dw}\right)$ was significantly higher $(\mathrm{p}<0.05)$ than that obtained from the previous study by Ntow (2001), possibly due to the accumulation of the residue in the environment over time.

\subsection{Ecotoxicological significance of measured pesticides in stream water}

To evaluate the ecotoxicological significance of pesticides contamination in streams, acute (ARR) and chronic (CRR) risk ratios were calculated for the water samples by comparing the pesticide concentrations in the samples with their toxicity values (Table 1).

The calculated risk ratios for acute toxicity are shown in Fig. 3. It was found that none of the detected pesticides had an acute risk ratio greater than 1 . Using the quantification limit of $0.01 \mu \mathrm{gL}^{-1}$, chlorpyrifos had a value of 1 in the streams. This means that when chlorpyrifos is detected in water, its concentration is already equal to its acute risk criteria. Thus, any occurrence of chlorpyrifos in water could pose a risk of acute toxicity to fish and crustaceans, and especially, species such as cladocerans, which have been observed to be highly sensitive to chlorpyrifos (Brock et al., 1992; van Wijngaarden et al., 2005). According to the fringing communities, fish is scarce in the streams within the catchments although fingerlings and other aquatic organisms such as frogs and crabs are present. Considering that the maximum concentrations found in this study are not the highest possible concentrations that can occur, compounds with a factor $>0.1$ could pose a moderate risk of acute toxicity. Also, for many compounds, there is not a large data set of toxicity values for aquatic organisms of different trophic levels. Furthermore, the great majority of compounds have not been tested with tropical organisms.

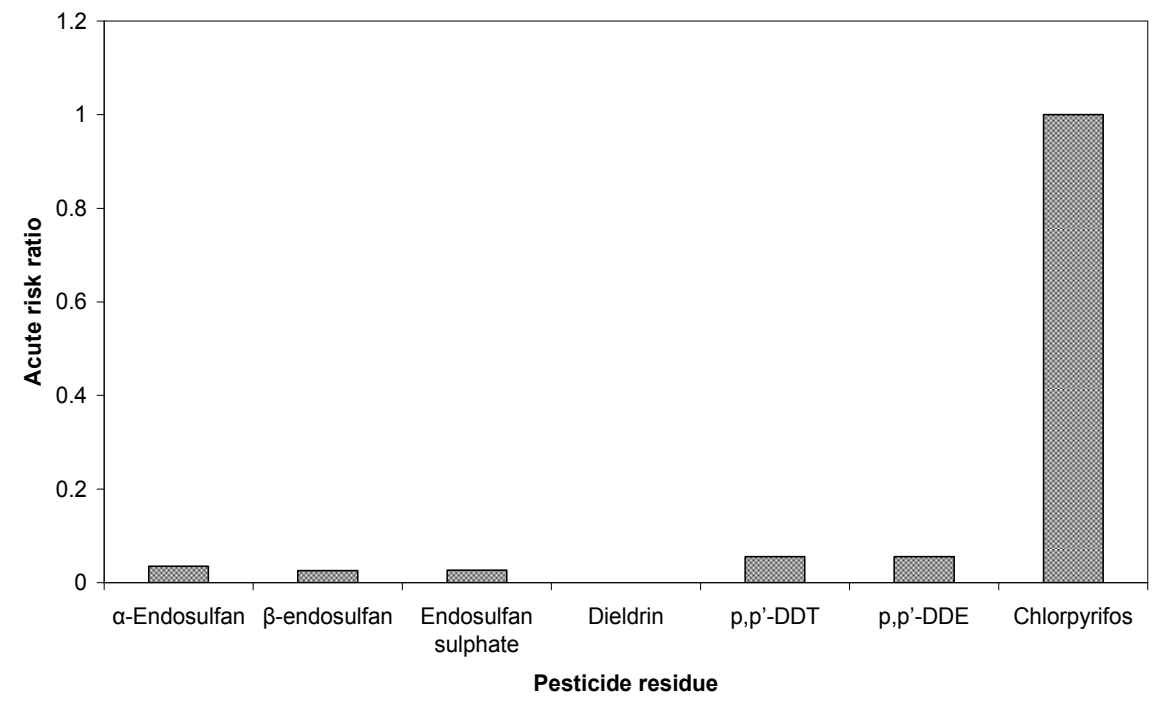

Fig. 3. Acute risk ratios for detected pesticides in stream water

The calculated risk ratios for chronic toxicity are shown in Fig. 4. It was found that DDT and DDE exceeded their chronic risk criteria in the streams. Although DDT and DDE were not 
detected in water at the quantification limit of $0.01 \mu \mathrm{gL}^{-1}$ in this study, the toxicity factor was considered relevant to estimate since the quantification limits for these pesticides were generally above their respective water quality criteria. For example, the water quality criterion for DDT and DDE is $0.001 \mu \mathrm{gL}^{-1}$ (Table 5) and the quantification limit was $0.01 \mu \mathrm{gL}-$ 1. This means that when DDT and DDE are detected, they have already exceeded their water quality criteria many times (see Figs. $3 \& 4$ ). The quantification limit was therefore used to calculate the toxicity factors. Thus, any occurrence of DDT and/or DDE in the streams is significant.

Endosulfan, dieldrin, DDE and chlorpyrifos are among the pesticides that are very toxic to fish and many aquatic invertebrate species. There were no records of fish or amphibian kills in the streams at the time of the study. However, simultaneous exposure to multiple contaminants is known to produce an additive, and sometimes even synergistic and complex effects in organisms which can affect the abundance and diversity of non-target species and alter trophic interactions (Rovedatti et al., 2001). Sediment is an important reservoir of contaminants, acting as both an ultimate sink and potential source via a series of biogeochemical processes (Guo et al., 2009). Pesticide contamination of sediments may thus lead to exposure of sediment-dwelling organisms to repeated pulses or fluctuating concentrations of pesticides (Reinert et al., 2002). There is therefore the need to assess the impact of water and sediment contamination on species abundance and diversity in these aquatic systems.

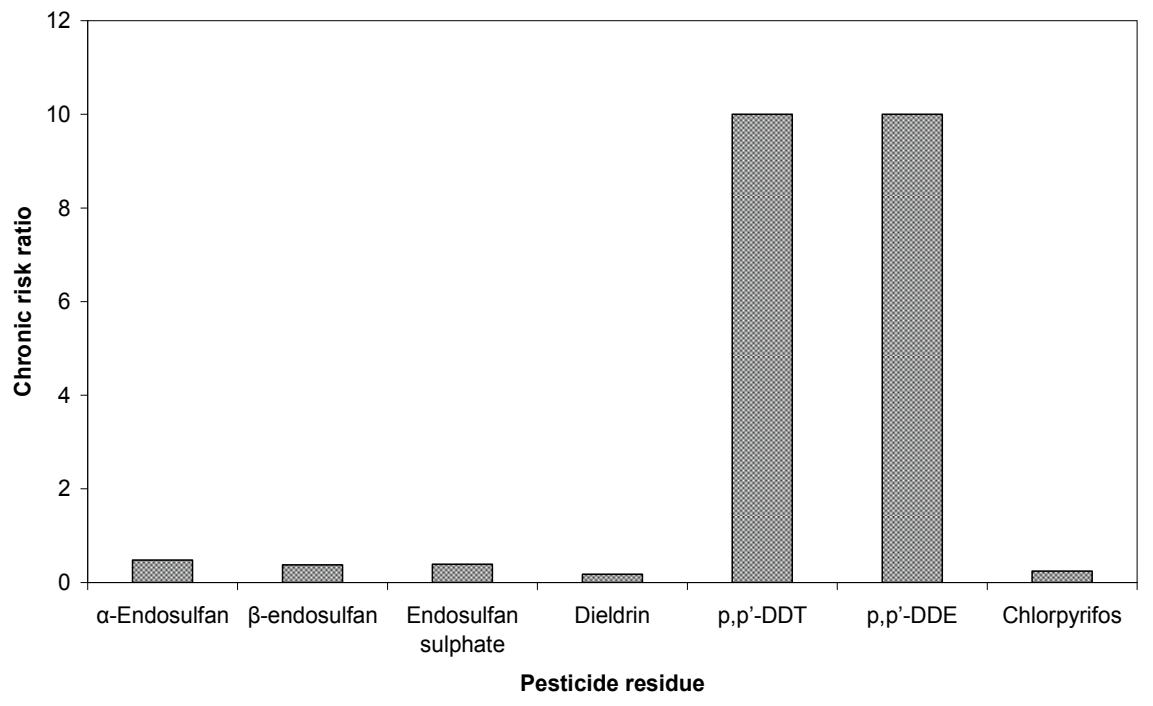

Fig. 4. Chronic risk ratios for detected pesticides in stream water

\section{Conclusion}

The results of this study have provided an insight into the levels of pesticide residue contamination in streams flowing in and around vegetable plantations in the Ofinso District of Ghana. Among the pesticides detected, endosulfan was the compound with the highest 
incidence of occurrence in both water and sediment, which is also the most frequently used pesticide in the study area. Sediment samples exhibited greater number and higher concentrations of pesticides residues than stream water samples. Although acute and chronic risk ratios indicated that the concentrations of the detected pesticide residues in streams did not surpass aquatic quality criteria, the presence of endosulfan in stream water has implications for public health. The use of endosulfan in agriculture should continue to be carefully monitored given its persistence, bioaccumulation, and continued release into streams. An extension of both the study areas and range of pesticides residues analyzed should be considered in future work.

\section{Acknowledgement}

The authors wish to express their gratitude to the Royal Netherlands Academy of Arts and Sciences (KNAW) for financial support. The Kinneret Limnological Laboratory, Migdal, Israel, is acknowledged for technical assistance in the use of GC/MS.

\section{References}

Amoah, P.; Drechsel, P.; Abaidoo, R. C. \& Ntow, W. J. (2006). Pesticide and pathogen contamination of vegetables in Ghana's urban markets. Archives of Environmental Contamination and Toxicology, Vol. 50, pp. 1-6.

Ballschmiter, B. \& Wittlinger, R. (1991). Interhemispheric exchange of hexachlorocyclohexanes, hexachlorobenzene, polychlorobiphenyls, and 1,1,1-trichloro-2,2-bis( $p$ chlorophenyl) ethane in the lower troposphere. Environment, Science ETechnology, Vol. 25, pp. 1103-1111.

Brock, T. C. M.; Crum, S. J. H.; van Wijngaarden, R.; Budde, B. J.; Tijink, J.; Zuppelli, A. \& Leeuwangh, P. (1992). Fate and effects of the insecticide Dursbans 4E in indoor Elodea-dominated and macrophyte-free freshwater model ecosystems: I. Fate and primary effects of the active ingredient chlorpyrifos. Archives of Environmental Contamination and Toxicology, Vol. 23, pp. 69-84.

Castillo, L. E.; Ruepert, C. \& Solis, E. (2000). Pesticide residues in the aquatic environment of banana plantation areas in the North Atlantic Zone of Costa Rica. Environmental Toxicology and Chemistry, Vol. 19, No. 8, pp. 1942-1950.

Colborn, T. \& Smolen, M. J. (1996). Epidemiological analysis of persistent oranochlorine contaminants in cetaceans. A review. Environmental Contamination and Toxicology, Vol. 146, pp. 92-172.

Darko, G. \& Akoto, O. (2008). Dietary intake of organophosphorus pesticide residues through vegetables from Kumasi, Ghana. Food and Chemical Toxicology, Vol. 46, pp. 3703-3706

DeLorenzo, M. E.; Scott, G. I. \& Ross, P. E. (2001). Toxicity of pesticides to aquatic microorganisms: A review. Environmental Toxicology and Chemistry, Vol. 20, No. 1, pp. 84-98.

Dinham, B. (2003). Growing vegetables in developing countries for local urban populations and export markets: Problems confronting small-scale producers. Pest Management Science, Vol. 59, pp. 575-582.

EXTOXNET (Extension Toxicology Network) (1996). Pesticides Information Profiles. 17.11.2008, Available from http:/ / extoxnet.orst.edu/pips/ghindex.html. 
García de Llasera, M. P. \& Bernal-González, M. (2001). Presence of carbamate pesticides in environmental waters from the Northwest of Mexico: Determination by Liquid Chromatography. Water Research, Vol. 35, pp. 1933-1940.

Guo, Y.; Yu, H-Y. \& Zeng, E. Y. (2009) Occurrence, source diagnosis, and biological effect assessment of DDT and its metabolites in various environmental compartments of the Pearl River Delta, South China: A review. Environmental Pollution, Vol. 157,pp. 1753-1763

Hoffman, R. S.; Capel, P. D. \& Larson, S. J. (2000). Comparison of pesticides in eight U.S. Urban streams. Environmental Toxicology and Chemistry, Vol. 19, No. 9, pp. 22492258.

Kidd, K. A.; Bootsma, H. A. \& Hesslein, R. H. (2001). Biomagnification of DDT through the benthic and pelagic food webs of Lake Malawi, East Africa: Importance of trophic level and carbon source. Environmental Science and Technology, Vol. 35, pp. 14-20.

Maule, A. G.; Gannam, A. L. \& Davis, J. W. (2007). Chemical contaminants in fish feeds used in federal salmonid hatcheries in the USA. Chemosphere, Vol. 67, pp. 1308-1315.

Mwamburi, J. (2003). Variations in trace elements in bottom sediments of major rivers in Lake Victoria's basin, Kenya. Lakes $\mathcal{E}$ Reservoirs: Research and Management, Vol. 8, pp. 5-13.

Munn, M. D. \& Gruber, S. J. (1997). The relationship between land use and organochlorine compounds in streambed sediment and fish in the Central Columbia Plateau, Washington and Idaho, USA. Environmental Toxicology and Chemistry, Vol. 16, pp. 1877-1887.

Ntow, W. J. \& Botwe, B. O. (2011). Contamination status of organochlorine pesticides in Ghana. In: Global Contamination Trends of Persistent Organic Chemicals, Eds. Loganathan, B. G. \& Lam, P. K. S., pp. 393-411, CRC Press, Boca Raton, FL., USA.

Ntow, W. J.; Drechsel, P.; Botwe, B. O.; Kelderman, P \& Gijzen, H. J. (2008). The impact of agricultural runoff on the quality of two streams in vegetable farm areas in Ghana. Journal of Environmental Quality, Vol. 37, pp. 696-703.

Ntow, W. J.; Gijzen, H. J.; Kelderman, P. \& Drechsel, P. (2006). Farmer perceptions and pesticide use practices in vegetable production in Ghana. Pest Management Science, Vol. 64, No. 4, pp. 356-365.

Ntow, W. J. (2005). Pesticide residues in Volta Lake, Ghana. Lakes \& Reservoirs: Research and Management, Vol. 10, No. 4, pp. 243-248.

Ntow, W. J. (2001). Organochlorine pesticides in water, sediment, crops and human fluids in a farming community in Ghana. Archives of Environmental Contamination and Toxicology, Vol. 40, pp. 557-563.

Osafo, S. \& Frimpong, E. (1998). Lindane and endosulfan residues in water and fish in the Ashanti region of Ghana. Journal of the Ghana Science Association, Vol. 1, pp. 135-140.

Pérez-Ruzafa, A.; Navarro, S.; Barba, A.; Marcos, C.; Cámara, A.; Salas, F. \& Gutiérrez, J. M. (2000). Presence of pesticides throughout trophic compartments of the food web in the Mar Menor lagoon (SE Spain). Marine Pollution Bulletin, Vol. 40, pp. 140-151.

Pignatello, J. J. (1998). Soil organic matter as a nanoporous sorbent of organic pollutants. Advances in Colloid Interface Science, Vol. 76-77, pp. 445-467.

Reinert, K. H.; Giddings, J. M. \& Judd, L. (2002). Effects of analysis of time varying or repeated exposures in aquatic ecological risk assessment of organochemicals. Environmental Toxicology \& Chemistry, Vol. 21, pp. 1977-1992. 
Robinson, A. Y. (1991). Sustainable Agriculture: The Wildlife Connection. American Journal of Alternative Agriculture, Vol. 6, No. 4, pp. 161-167.

Rovedatti, M. G.; Castañé, P. M.; Topalián, M. L. \& Salibián, A. (2001). Monitoring of organochlorine and organophosphorus pesticides in the water of the Reconquista River (Buenos Aires, Argentina). Water Research, Vol. 35, pp. 3457-3461.

Skinner, J. A.; Lewis, K. A.; Bardon, K. S.; Tucker, P.; Catt, J. A. \& Chambers, B. J. (1997). An overview of the environmental impact of agriculture in the U.K. Journal of Environmental Management, Vol. 50, pp. 111-128

United States Environmental Protection Agency (USEPA). (1999). National recommended water quality criteria. USEPA 822-Z-99-001. Washington, DC.

van Wijngaarden, R. P. A.; Brock, T. C. M. \& Douglas, M. T. (2005). Effects of chlorpyrifos in freshwater model ecosystems: the influence of experimental conditions on ecotoxicological thresholds. Pest Management Science, Vol. 61, pp. 923-935.

Wan, M. T.; Kuo, J.; Buday, C.; Schroeder, G.; Van Aggelen, G. \& Pasternak, J. (2005). Toxicity of $\alpha-, \beta-,(\alpha+\beta)$-endosulfan and their formulated and degradation products to Daphnia magna, Hyalella azteca, Oncorhynchus mykiss, Oncorhynchus kisutch, and biological implications in streams. Environmental Toxicology $\mathcal{E}$ Chemistry, Vol. 24, pp. 1146-1154. 


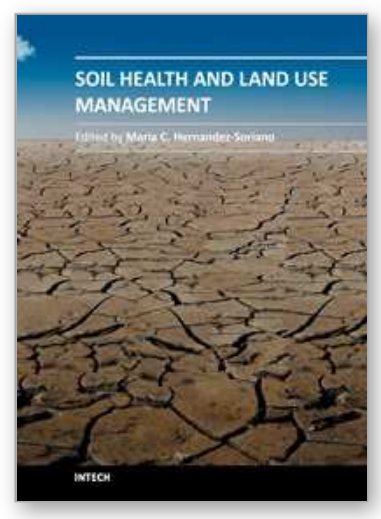

\author{
Soil Health and Land Use Management
}

Edited by Dr. Maria C. Hernandez Soriano

ISBN 978-953-307-614-0

Hard cover, 332 pages

Publisher InTech

Published online 25, January, 2012

Published in print edition January, 2012

Soils play multiple roles in the quality of life throughout the world, not only as the resource for food production, but also as the support for our structures, the environment, the medium for waste disposal, water, and the storage of nutrients. A healthy soil can sustain biological productivity, maintain environmental quality, and promote plant and animal health. Understanding the impact of land management practices on soil properties and processes can provide useful indicators of economic and environmental sustainability. The sixteen chapters of this book orchestrate a multidisciplinary composition of current trends in soil health. Soil Health and Land Use Management provides a broad vision of the fundamental importance of soil health. In addition, the development of feasible management and remediation strategies to preserve and ameliorate the fitness of soils are discussed in this book. Strategies to improve land management and relevant case studies are covered, as well as the importance of characterizing soil properties to develop management and remediation strategies. Moreover, the current management of several environmental scenarios of high concern is presented, while the final chapters propose new methodologies for soil pollution assessment.

\title{
How to reference
}

In order to correctly reference this scholarly work, feel free to copy and paste the following:

Benjamin O. Botwe, William J. Ntow and Elvis Nyarko (2012). Pesticide Contamination in Groundwater and Streams Draining Vegetable Plantations in the Ofinso District, Ghana, Soil Health and Land Use Management, Dr. Maria C. Hernandez Soriano (Ed.), ISBN: 978-953-307-614-0, InTech, Available from: http://www.intechopen.com/books/soil-health-and-land-use-management/pesticide-contamination-ingroundwater-and-streams-draining-vegetable-plantations-in-the-ofinso-dist

\section{INTECH}

open science | open minds

\section{InTech Europe}

University Campus STeP Ri

Slavka Krautzeka 83/A

51000 Rijeka, Croatia

Phone: +385 (51) 770447

Fax: +385 (51) 686166

www.intechopen.com

\section{InTech China}

Unit 405, Office Block, Hotel Equatorial Shanghai

No.65, Yan An Road (West), Shanghai, 200040, China

中国上海市延安西路 65 号上海国际贵都大饭店办公楼 405 单元

Phone: +86-21-62489820

Fax: $+86-21-62489821$ 
(C) 2012 The Author(s). Licensee IntechOpen. This is an open access article distributed under the terms of the Creative Commons Attribution 3.0 License, which permits unrestricted use, distribution, and reproduction in any medium, provided the original work is properly cited. 